\section{Seasonal Variations in Fig (Ficus carica L.) Leaf Nutrient Concentrations}

\author{
Patrick H. Brown ${ }^{1}$ \\ Department of Pomology, University of California, Davis, CA 95616-8683
}

Additional index words. 'Calimyrna' fig, Sari Lop fig, nutrition, micronutrients, macronutrients

\begin{abstract}
Concentrations of $\mathrm{N}, \mathrm{P}, \mathrm{K}, \mathrm{Ca}, \mathrm{Mg}, \mathrm{B}, \mathrm{Fe}, \mathrm{Cu}, \mathrm{Zn}$, and $\mathrm{Mn}$ in mature commercial fig ('Calimyrna'; 'Sari Lop' ) leaves are presented throughout the growing season. These data can be used as preliminary norms for the interpretation of tree nutrient status for high-yielding commercial fig orchards. In comparison with other deciduous tree crops growing in the same regions \{almond [Prunus amygdalus Batsch syn. P. dulcis (Mill) D.A. Webb], walnut (Juglans regia $\mathrm{L}$.), peach $[$ Prunus persica $(\mathrm{L}$.) Batsch]\}, productive fig trees have relatively low leaf $\mathrm{N}, \mathrm{P}$, and $\mathrm{K}$ concentrations $(2.1 \%, 0.1 \%$, and $1.0 \%$ dry weight, respectively) in July, although tissue $\mathrm{Mn}$ and $\mathrm{Ca}$ concentrations often exceed those typically found in other deciduous species growing in the same soils. Seasonal variations in fig leaf nutrient concentrations are similar to those of other tree crops. Marked declines in tissue $K$ and $N$ concentrations toward the end of the season may indicate a need for supplemental $\mathbf{N}$ and $\mathbf{K}$ fertilization in highly productive orchards. The potential for $K$ deficiency in fig also is indicated by the generally lower leaf $K$ concentrations in the lowvigor orchards examined.
\end{abstract}

The fig is perhaps the oldest of all cultivated fruit species and has been grown commercially in the United States for $>100$ years. In California, $>8000$ ha produce a farm gate value of $>15$ million dollars annually. Nevertheless, information on the nutritional requirements of fig is scarce (Condit and Enderud, 1956), and to our knowledge, there have been no reports on irrigated, commercial fig orchards in the United States. Moreover in other fig-producing countries (notably Greece, Egypt, and Turkey), little information is available, and generally, it relates to nonirrigated trees for which the management system, species identification, and basis for recommendations are uncertain (see Ismail and Habeeb, 1989).

General opinion has long held that fig performs well under soil conditions unsuitable for most other commercial tree crops. In many of the historical fig-producing regions, the only fertilization practiced, if any, is applying fertilizer or manure to intercrops between the tree rows. Chandler (1951) suggested that fig trees would do well at soil $\mathrm{N}$ levels that would severely inhibit the peach productivity. Condit (1947) reported that supplemental $\mathrm{N}$ fertiliza-

Received for publication 22 Nov. 1993. Accepted for publication 2 Feb. 1994. This research was supported by a grant from the California Fig Institute. I thank Anne Whittlesey, Qinglong Zhang, and Abdul Jalil for help with sample collection and analysis. Mention of a product or trade name does not imply endorsement or recommendation of the product. The cost of publishing this paper was defrayed in part by the payment of page charges. Under postal regulations, this paper therefore must be hereby marked advertisement solely to indicate this fact.

${ }^{1}$ Assistant Professor.

HortScience, Vol. 29(8), August 1994
1986). An alternative approach to determining these critical nutritional norms is to extensively sample orchards that vary in vigor and productivity. Nutritional concentrations in high-yielding orchards then are presumed to be optimal. This methodology is the most common source of our current tree crop nutritional information (Reuter and Robinson, 1986). However, this methodology overlooks other factors, such as management, irrigation, pests, and diseases, that may be independent of nutrition but still influence productivity. My objective was to provide preliminary information for the interpretation of fig leaf nutrient data.

\section{Materials and Methods}

Eight, high-yielding, mature (>17 years old) 'Calimyrna' fig orchards were surveyed. Orchards were located on well-drained San Joaquin series, sandy loam and loam soils with surface soil $(0$ to $20 \mathrm{~cm}) \mathrm{pH}$ values ranging from 5.2 to 6.8, in the Fresno, Madera, and Modesto counties of California. All were wellmanaged, irrigated orchards with mean yields in excess of the state $2.4 \mathrm{t} \cdot \mathrm{ha}^{-1}$ (in field weight) average (California Fig Institute, 1991). Two areas of low-vigor trees within two of these orchards also were sampled. These trees were identified by their smaller size and $\approx 30 \%$ to $50 \%$ less fruit per tree. Low-vigor site 1 was an area of 100 trees in which soil levelling had exposed areas of clay subsoil; the soil in this area had a $\mathrm{pH}$ of 6.7 and was deep and moderately well-drained. Low-vigor site 2 also consisted of $\approx 100$ trees and was typified by sandy loam soils with a surface $(0$ to $20 \mathrm{~cm}) \mathrm{pH}$ from 4.8 to 5.2. None of the sites had any significant disease problem. All orchards were cleancultivated throughout the growing season, irrigated by flooding (five orchards) or microsprinkler (three orchards), and fertilized with $50 \mathrm{~kg} \mathrm{~N} / \mathrm{ha}$ in early spring, with no other fertilizer applied.

In each orchard, 10 uniform and representative trees were selected for analysis. Twentyleaf samples of the youngest fully expanded, exposed leaves on nonfruiting branches were collected from the perimeter of each tree at a 2.5-m height, according to the methods of Beutel et al. (1983). Leaf nutrient concentration determinations of deciduous crops normally are made on leaves collected in midsummer (late July to early August in California; Beutel et al., 1983). In this survey, leaf samples were collected in May, July, Sept., and Oct. 1990, 1991, and 1992. At each of the 10 sites (eight orchards plus two low-vigor sites), 10 trees were sampled at each sampling date and in each year for a total of 100 trees $x$ 4 times $\times 3$ years. Statistical analysis of individual site data indicated that leaf nutrient concentrations did not differ significantly between years at a given sampling time $(P \geq$ $0.05)$; thus, data for all years were pooled at each sampling time. There were no statistical differences in leaf nutrient concentrations between any of the eight high-vigor sites at a given sampling date; thus, data for all highvigor sites were pooled. The two low-vigor 
sites did differ significantly from the highvigor sites for several elements; therefore, I am discussing them separately. Data are expressed as the leaf nutrient concentration mean over 3 years at each sampling date $( \pm \mathrm{SE})$. Statistical analyses of individual site and year effects were performed by analysis of variance (Superanova; Abacus Concepts, Berkeley, Calif.); pooled data were analyzed further by a two-tailed $t$ test (Statview II; Abacus Concepts).

Leaf samples were washed with distilled water, soaked briefly in $0.1 \mathrm{~N} \mathrm{HCl}$, rinsed three times with deionized water, dried in a forcedair oven at $70 \mathrm{C}$, and then ground to pass an $\approx 0.4$-mm-diameter (40 mesh) screen. A subsample was ashed in a muffle furnace at $200 \mathrm{C}$ for $2 \mathrm{~h}$ and then at $500 \mathrm{C}$ for an additional $12 \mathrm{~h}$. Ashed samples were dissolved in $0.1 \mathrm{~N}$ $\mathrm{HNO}_{3}$ and then analyzed for $\mathrm{P}, \mathrm{K}, \mathrm{Ca}, \mathrm{Mg}, \mathrm{Zn}$, $\mathrm{Cu}, \mathrm{Mn}, \mathrm{B}$, and $\mathrm{Fe}$ by inductively coupled argon plasma spectroscopy (ICP-AES model 3500; Applied Research Laboratories, Sunland, Calif.). Nitrogen was determined by modified macro-Kjeldahl digestion with the addition of salicylic acid (Weinbaum and Neumann, 1977).

\section{Results and Discussion}

Nutrient concentrations for all elements changed seasonally (Tables 1 and 2). This is a typical response for deciduous fruit trees and emphasizes the need to consider sampling date in any assessment of tree nutrient status. My results have not been used to define an optimum sampling time for fig; however, the data are useful for estimating fig tree nutrient status at any of the four sampling times.

Mean leaf $\mathrm{N}$ concentrations averaged between $2.3 \%$ in late spring and $1.5 \%$ in late summer and fall (Table 1). Nitrogen concentrations declined until fruit were harvest in late summer. No significant differences in $\mathrm{N}$ concentration existed between high- and lowvigor orchards. Proebsting and Warner (1954) reported slightly higher spring $\mathrm{N}$ concentrations than I observed and indicated that additional $\mathrm{N}$ fertilization did not result in significant yield increases.

The $P$ requirement of deciduous tree crops is largely unknown. The July values of $0.12 \%$ to $0.13 \%$ (Table 1) are low compared to most other tree crops (Beutel et al., 1983; Reuter and Robinson, 1986). Proebsting and Warner (1954) reported similar $P$ values in fig. Low $P$ concentrations also are observed in cleancultivated blueberry (Vaccinium corymbosum L.) and apple (Malus pumila Mill.) orchards (Faust, 1989), where they are thought to be caused by the lack of mycorrhizae in cleancultivated land (Faust, 1989). Many species of fig are known to be mycorrhizal, although commercial fig has not been assessed (C. Bledsoe, personal communication).

Potassium was the most variable element, with leaf $\mathrm{K}$ concentrations in July ranging from $0.5 \%$ to $1.0 \%$ across the 10 sites examined. As with most deciduous crop species, tissue $\mathrm{K}$ concentrations decline as the season progresses. In fig, this decline is particularly marked and may be associated with the rela- tively high $\mathrm{K}$ content of the fig crop. Typical K concentrations are in the range of $0.5 \%$ to $1 \%$ of fig fruit dry weight (Watt and Merrill, 1963). For a 3-t crop (a typical good yield), this concentration represents an annual removal of 15 to $30 \mathrm{~kg} \mathrm{~K} / \mathrm{ha}$. In general, fertilizer $\mathrm{K}$ is not supplied to commercial fig orchards. The two low-vigor sites in this study contained the lowest K concentrations. For these sites, leaf $\mathrm{K}$ concentrations in July ranged from $0.5 \%$ to $0.6 \% \mathrm{~K}$, which is below the currently accepted critical values for other deciduous tree crops (Jones et al., 1991). Tissue K concentrations also declined by final harvest in these orchards. At that time, most trees had leaf $\mathrm{K}$ concentrations of $\approx 0.3 \%$. Such low K concentrations would be regarded as deficient in most other deciduous tree crops (K.Uriu and J. Beutel, personal communication). Tree vigor was associated with leaf $K$ concentrations, but I did not determine whether $\mathrm{K}$ levels in the highest producing orchards were optimal. In comparison with other deciduous tree crops, leaf $\mathrm{K}$ concentrations in the high-yielding orchards were low and declined through the season (Beutel et al., 1983).

Magnesium and $\mathrm{Ca}$ leaf concentrations were adequate or high, compared to those of other species. There was no association between plant vigor and tissue $\mathrm{Ca}$ or $\mathrm{Mg}$ concentrations (Table 1). Leaf $\mathrm{Ca}$ and $\mathrm{Mg}$ concentrations increased throughout the year, as is typical for these elements. This indicates their transpirational driven flux and relatively low phloem mobility (Marschner, 1986).

Fig leaf $\mathrm{Cu}$ and $\mathrm{Fe}$ concentrations were typical of those for other species growing in these soils (Table 2). For most tree species, $\mathrm{Cu}$ and Fe concentrations in July at $>4 \mathrm{ppm}$ and 70 ppm, respectively, are considered adequate (Jones et al., 1991). By this criterion, all orchards sampled would be considered adequate. There was no relationship between vigor and leaf $\mathrm{Fe}$ or $\mathrm{Cu}$ concentrations.

Leaf $\mathrm{Zn}$ concentrations ranged from 12 to 14 ppm in July samples. These concentrations

Table 1. Mean macronutrient concentrations (percentage of dry weight) in fig leaves collected on four sampling dates from trees in eight high-vigor and one low-vigor site within each of two of those orchards. For high-vigor orchards, each mean $( \pm \mathrm{SD})$ is for 10 trees at each of eight orchards for three consecutive years $(n=240)$. The values for each low-vigor site are the mean $( \pm$ SD $)$ of 10 trees for three consecutive years $(n=30)$

\begin{tabular}{|c|c|c|c|c|c|c|}
\hline $\begin{array}{l}\text { Sampling } \\
\text { time }\end{array}$ & Development stage & $\mathrm{N}$ & $\mathrm{P}$ & $\mathrm{K}$ & $\mathrm{Ca}$ & $\mathrm{Mg}$ \\
\hline \multicolumn{7}{|c|}{ High-vigor sites } \\
\hline May & Flowering & $2.3 \pm 0.05$ & $0.14 \pm 0.02$ & $1.4 \pm 0.3$ & $3.0 \pm 0.4$ & $0.7 \pm 0.1$ \\
\hline July & Fruit development & $2.1 \pm 0.3$ & $0.12 \pm 0.01$ & $1.0 \pm 0.3$ & $3.0 \pm 0.3$ & $0.7 \pm 0.1$ \\
\hline September & Fruit maturity & $1.6 \pm 0.1$ & $0.11 \pm 0.02$ & $0.7 \pm 0.4$ & $2.9 \pm 0.5$ & $0.8 \pm 0.2$ \\
\hline October & Postharvest & $1.5 \pm 0.1$ & $0.09 \pm 0.03$ & $0.7 \pm 0.3$ & $3.5 \pm 0.4$ & $0.8 \pm 0.2$ \\
\hline \multicolumn{7}{|c|}{ Low-vigor site 1} \\
\hline May & Flowering & $2.1 \pm 0.05$ & $0.14 \pm 0.03$ & $0.7 \pm 0.3^{z}$ & $3.1 \pm 0.4$ & $0.7 \pm 0.3$ \\
\hline July & Fruit development & $1.8 \pm 0.2$ & $0.13 \pm 0.05$ & $0.5 \pm 0.2^{z}$ & $3.0 \pm 0.5$ & $0.7 \pm 0.1$ \\
\hline September & Fruit maturity & $1.5 \pm 0.2$ & $0.10 \pm 0.03$ & $0.25 \pm 0.2^{z}$ & $2.8 \pm 0.6$ & $0.8 \pm 0.2$ \\
\hline October & Postharvest & $1.5 \pm 0.4$ & $0.09 \pm 0.04$ & $0.25 \pm 0.2^{z}$ & $3.3 \pm 0.5$ & $0.8 \pm 0.2$ \\
\hline \multicolumn{7}{|c|}{ Low-vigor site 2} \\
\hline May & Flowering & $2.3 \pm 0.04$ & $0.12 \pm 0.02$ & $0.9 \pm 0.3^{z}$ & $2.8 \pm 0.4$ & $0.7 \pm 0.1$ \\
\hline July & Fruit development & $2.2 \pm 0.3$ & $0.12 \pm 0.03$ & $0.6 \pm 0.4^{z}$ & $2.9 \pm 0.2$ & $0.9 \pm 0.2$ \\
\hline September & Fruit maturity & $1.8 \pm 0.1$ & $0.10 \pm 0.02$ & $0.35 \pm 0.4^{z}$ & $2.9 \pm 0.5$ & $0.8 \pm 0.2$ \\
\hline October & Postharvest & $1.9 \pm 0.4$ & $0.08 \pm 0.04$ & $0.35 \pm 0.2^{z}$ & $3.2 \pm 0.6$ & $0.7 \pm 0.4$ \\
\hline
\end{tabular}

${ }^{z}$ Value differs significantly from that of high-vigor plants within sampling time $(P \leq 0.05)$.

Table 2. Mean micronutrient concentrations (ppm dry weight) in fig leaves collected on four sampling dates from trees in eight high-vigor and one low-vigor site within each of two of those orchards. For high-vigor orchards, each mean $( \pm \mathrm{SD})$ is for 10 trees at each of eight orchards for three consecutive years $(\mathrm{n}=240)$. The values for each low-vigor site are the mean $( \pm$ SD) of 10 trees for three consecutive years $(n=30)$.

\begin{tabular}{|c|c|c|c|c|c|c|}
\hline $\begin{array}{l}\text { Sampling } \\
\text { time }\end{array}$ & Development stage & $\mathrm{Zn}$ & $\mathrm{Cu}$ & $\mathrm{B}$ & $\mathrm{Mn}$ & $\mathrm{Fe}$ \\
\hline \multicolumn{7}{|c|}{ High-vigor sites } \\
\hline May & Flowering & $12 \pm 0.2$ & $6 \pm 4$ & $65 \pm 15$ & $80 \pm 20$ & $120 \pm 45$ \\
\hline July & Fruit development & $12 \pm 2$ & $6 \pm 1$ & $100 \pm 45$ & $90 \pm 25$ & $110 \pm 12$ \\
\hline September & Fruit maturity & $12 \pm 4$ & $5 \pm 2$ & $125 \pm 45$ & $145 \pm 45$ & $125 \pm 23$ \\
\hline October & Postharvest & $9 \pm 1$ & $4 \pm 2$ & $110 \pm 25$ & $150 \pm 54$ & $78 \pm 22$ \\
\hline \multicolumn{7}{|c|}{ Low-vigor site 1} \\
\hline May & Flowering & $12 \pm 0.2$ & $6 \pm 2$ & $54 \pm 12$ & $80 \pm 20$ & $120 \pm 23$ \\
\hline July & Fruit development & $12 \pm 2$ & $6 \pm 1$ & $85 \pm 25$ & $110 \pm 25$ & $100 \pm 13$ \\
\hline September & Fruit maturity & $12 \pm 4$ & $5 \pm 4$ & $90 \pm 12$ & $165 \pm 55$ & $129 \pm 34$ \\
\hline October & Postharvest & $9 \pm 1$ & $5 \pm 2$ & $110 \pm 20$ & $166 \pm 23$ & $87 \pm 12$ \\
\hline \multicolumn{7}{|c|}{ Low-vigor site 2} \\
\hline May & Flowering & $14 \pm 3$ & $6 \pm 4$ & $69 \pm 18$ & $190 \pm 45^{z}$ & $145 \pm 22$ \\
\hline July & Fruit development & $14 \pm 5$ & $7 \pm 1$ & $110 \pm 23$ & $250 \pm 55^{z}$ & $122 \pm 23$ \\
\hline September & Fruit maturity & $13 \pm 3$ & $8 \pm 2$ & $135 \pm 49$ & $400 \pm 200^{z}$ & $165 \pm 29^{z}$ \\
\hline October & Postharvest & $12 \pm 6$ & $6 \pm 1$ & $140 \pm 55$ & $450 \pm 190^{z}$ & $120 \pm 29^{z}$ \\
\hline
\end{tabular}

${ }^{\mathrm{z}}$ Value differs significantly from that of high-vigor plants within sampling time $(P \leq 0.05)$. 
would be considered marginal in most tree crop species (Beutel et al., 1983), indicating that either fig has a low $\mathrm{Zn}$ requirement or that fig is relatively inefficient at obtaining $\mathrm{Zn}$ from these soils. Based on observations of other crops, the soils involved in these studies would not be considered $\mathrm{Zn}$ deficient. There was, however, no clear relationship between tree vigor and $\mathrm{Zn}$ status.

Boron accumulated in fig leaf tissues with the season's progression, and B concentrations varied widely between sites (Table 2). Of the orchards examined, B levels were lowest in low-vigor site 1 (Table 2). July B values ranged from 85 to $110 \mathrm{ppm}$. At the low end of this range, $\mathrm{B}$ would be considered adequate for Prunus but deficient for pistachio (Pistacia vera L.) (Brown et al., 1992) or walnut (Beutel et al., 1983; Reuter and Robinson, 1986).

Determining average or normal B levels for fruit trees is more difficult than for any other element. Boron concentrations vary greatly between tree species and locations, perhaps because of differences in soils and water and the fundamental differences in $\mathrm{B}$ partitioning within plants. Prunus species [peach (Prunus persica L. Batsch), almond (Prunus amygdalus L. Batsch), and plum (Prunus domestica L.)] tend not to accumulate $\mathrm{B}$ in leaf tissue, whereas walnut, pistachio, and kiwi accumulate $B$ to high levels in leaf tissue when B levels are high in the soil or water (Brown, unpublished data). Fig seems to be a $\mathrm{B}$ accumulator, similar to walnut and pistachio. Estimates of plant B requirements are poorly defined for most species due in part to $B$ requirements for flowering and fruit production being higher than the requirements for vegetative growth (Hansen et al., 1985).

Manganese levels tended to be high compared to other crops (Table 2). Fig leaf Mn concentrations in July ranged from 90 to 250 ppm-well above the critical value for many species. In September, these values approach the potentially toxic concentrations of 600 $\mathrm{ppm}$ in some trees. Such levels were associated with one of the least vigorous and poorest yielding orchards and also were generally associated with more acid ( $\mathrm{pH} 5.0$ to 5.5) soils.

The data presented here represent the best estimates of the leaf nutrient concentrations required for good fig tree productivity. Considerable variation in mean leaf nutrient concentrations ( $\pm 10 \%$ to $30 \%$ ) was evident throughout this study, which can be attributed to several causes. Though trees were chosen for uniformity, some variation in growth and productivity were apparent. Crop demand for phloem-mobile nutrients $(\mathrm{N}, \mathrm{K}$, and $\mathrm{P})$ is known to influence leaf nutrient concentrations (Balasubrahmanyam et al., 1978). For the mi- cronutrients ( $\mathrm{Mn}, \mathrm{Fe}, \mathrm{Zn}$, and $\mathrm{Cu}$ ), inconsistencies in elemental analysis and contamination with particulate matter often increase variability; however, for the phloem-immobile elements (B, Ca, and $\mathrm{Mg}$ ), slight differences in leaf age and exposure can significantly affect leaf concentration. High variability also existed at the end of the growing season, a time when nutrients are being differentially remobilized out of the leaf tissue.

In comparison with recommended leaf nutrient concentrations for other fruit tree species, the N, P, K, and $\mathrm{Zn}$ values for the fig trees studied were low; $\mathrm{Ca}$ and $\mathrm{Mg}$ values were high; Mn values were exceptionally high; and the $\mathrm{B}$ tissue levels were variable. Of these elements, only low $\mathrm{K}$ was consistently associated with low tree vigor. The high demand for $\mathrm{K}$ by the fig fruit, coupled with low tissue $\mathrm{K}$ concentrations compared to other crops, and the lowest leaf $\mathrm{K}$ concentrations in the low vigor orchards suggest that $\mathrm{K}$ deficiency may be present in these fig orchards. Potassium also plays an important role in the sun scald development on fig fruit (Aksoy et al., 1987). This disorder is common throughout the Turkish fig-growing regions where it is most prevalent in orchards of low $(<1.0 \%)$ leaf K concentrations in August. Fig sun scald significantly reduces fruit quality in many California regions, although the association between fig sun scald and leaf $\mathrm{K}$ concentrations has not been investigated and was not considered in this study. It is also significant that many trees sampled in this survey had leaf K concentrations $<1.0 \%$ in August.

In the orchards surveyed by Proebsting and Warner (1954), they recorded leaf K concentrations in July ranging from $1.5 \%$ to $1.9 \%$, significantly higher than those that I recorded. A direct comparison of results is difficult because Proebsting and Warner sampled basal leaves, whereas I used the youngest fully expanded blades. Also, the orchards used in their studies yielded $30 \%$ to $50 \%$ more fruit than the best orchard sampled here, and $\mathrm{K}$ fertilization did not increase yield (Proebsting and Warner, 1954). The possibility that the subsequent 50 years of cropping in this region has depleted soil K reserves cannot be ignored, particularly as fig is often planted on relatively poorer soils and typically does not receive supplemental $\mathrm{K}$ fertilization.

The leaf nutrient concentrations of the trees in the high-vigor orchards are proposed as tentative standards because they are currently the best and only estimates of the optimal leaf nutrient concentrations for fig. However, I emphasize that these data do not represent critical values for fig because I did not estimate yield-nutrient relationships. Although this research surveyed 'Calimyrna' orchards, preliminary studies suggest that similar nutrient concentrations may also be appropriate for 'Black Mission' and 'Adriatic'.

\section{Literature Cited}

Aksoy, U., D. Anac, H. Hakerlerler, and M. Düzbastilar. 1987. The nutritional status of fig (cv Sarilop) orchards of the Germenik district and the relationship between nutrition, yield and some quality properties. Taris Arge, Project no. 006. Ege Univ., Faculty of Agr., Turkey.

Balasubrahmanyam, V.R., J. Eifert, and L. Dofasi. 1978. Nutrient reserves in grapevine canes as influenced by cropping levels. Vitis 17:23-29.

Beutel, J., K. Uriu, and O. Lilleland. 1983. Leaf analysis for Californian deciduous fruits. Soil and Plant Tissue Testing in California Bul. 1879. Univ. of California, Berkeley.

Brown, P.H., L. Ferguson, and G.A. Picchioni. 1992. Boron nutrition of pistachio. Annu. Rpt. California Pistachio Industry, Fresno.

California Fig Industry. 1991. Statistical Review. California Fig Institute, Fresno.

Chandler, W.H. 1951. Deciduous orchards. 2nd ed. Lea and Febiger, Philadelphia.

Condit, I.J. 1947. The fig. Chronica Bot. Co., Waltham, Mass.

Condit, I.J. and J. Enderud. 1956. A bibliography of fig. Hilgardia 25:1-663.

El-Kassas, S.E. 1975. Effect of moisture levels and nitrogen fertilization on yield, shoot growth and leaf composition of fig trees. Ann. Moshtohor. 4:155-164.

Faust, M. 1989. Physiology of temperate zone fruit trees. John Wiley and Sons, New York.

Hansen, E.J., M.H. Chaplin, and P.J. Breen. 1985. Movement of foliar boron out of leaves and accumulation in flower buds and flower parts of 'Italian' prune. Hortscience 20:747-748.

Ismail, Z. and H. Habeeb. 1989. Nutrient application in different orchard species in Egypt. Ext. Bul. Hort. Res. Inst. Agr. Res. Centre, Giza, Egypt.

Jones, J.B., Jr., B. Wolf, and H.A. Mills. 1991. Plant analysis handbook. Micro-Macro Publishing, Athens, Ga.

Marschner, H. 1986. Mineral nutrition of higher plants. Academic, London.

Proebsting, E.L. and R.M. Warner. 1954. The effect of fertilizers on yield, quality and leaf composition of figs. Proc. Amer. Soc. Hort. Sci. 63:1018

Reuter, D.J. and J.B. Robinson. 1986. Plant analysis: An interpretation manual. Inkata Press, Victoria, Australia.

Smith, P.F. 1962. Mineral analysis in plant tissue. Annu. Rev. Plant Physiol. 13:81-108.

Watt, B.K. and A.C. Merrill (eds.). 1963. Composition of foods, p. 6-67. U.S. Dept. Agr. Hdbk 8. U.S. Dept. of Agr., Washington, D.C.

Weinbaum, S.A. and P.M. Neumann. 1977. Uptake and metabolism of $15 \mathrm{~N}$ labeled pottassium nitrate by french prune (Prunus domestica L.) leaves and the effects of two surfactants. J. Amer. Soc. Hort. Sci. 103:601-604. 